\title{
Changes in neurokinin A (NKA) airway responsiveness with inhaled frusemide in asthma
}

\author{
N Crimi, G Prosperini, I Ciamarra, C Mastruzzo, S Magri, R Polosa
}

\begin{abstract}
Background - Inhaled frusemide exerts a protective effect against bronchoconstriction induced by several indirect stimuli in asthma which could be due to interference of airway nerves. A randomised, double blind, placebo controlled study was performed to investigate the effect of the potent loop diuretic, frusemide, administered by inhalation on the bronchoconstrictor response to neurokinin A (NKA) and histamine in 11 asthmatic subjects.
\end{abstract}

Methods - Subjects attended the laboratory on four separate occasions to receive nebulised frusemide $(40 \mathrm{mg})$ or matched placebo 10 minutes prior to bronchial challenge with NKA and histamine in a randomised, double blind order. Changes in airway calibre were followed as forced expiratory volume in one second $\left(F E V_{1}\right)$ and responsiveness to the agonists was expressed as the provocative concentration causing a $20 \%$ fall in $\mathrm{FEV}_{1}$ from baseline $\left(\mathbf{P C}_{20}\right)$.

Results - Compared with placebo, inhaled frusemide reduced the airway responsiveness to NKA in all the subjects studied, the geometric mean (range) values for $\mathbf{P C}_{20}$ NKA increasing significantly $(p<0.001)$ from $130.3(35.8-378.8)$ to 419.9 (126.5-1000) $\mu \mathrm{g} / \mathrm{ml}$ after placebo and frusemide, respectively. Moreover, a small but significant change in airway responsiveness to histamine was recorded after frusemide, their geometric mean (range) $\mathbf{P C}_{20}$ values being $0.58(0.12-3.80)$ and $1.04(0.28-4.33) \mathrm{mg} / \mathrm{ml}$ after placebo and frusemide, respectively.

Conclusions - The decrease in airway responsiveness to NKA after administration of frusemide by inhalation suggests that this drug may interfere with the activation of neurotransmission in human asthma.

(Thorax 1997;52:775-779)

Keywords: neurokinin A, frusemide, asthma, bronchoconstriction.

A number of studies have accumulated evidence showing an effect of loop diuretics in bronchial asthma. ${ }^{1}$ The inhalation of frusemide has been shown to protect the asthmatic airways against various bronchoconstrictor stimuli including allergen, ${ }^{2}$ ultrasonically nebulised distilled water, ${ }^{3}$ exercise, ${ }^{4}$ cold air, ${ }^{5}$ sodium metabisulphite, ${ }^{6}$ adenosine $5^{\prime}$-monophosphate (AMP), ${ }^{7}$ and bradykinin. ${ }^{8}$ Although the mechanisms underlying the protective effects of this drug against these different forms of provocation in asthma are not yet clear, an inhibitory effect on airway nerves has been suggested. In support of this, inhaled frusemide has been shown to inhibit the cough response induced by low chloride aerosols ${ }^{9}$ and to produce dose-dependent inhibition of the contractile response of airways smooth muscle induced by the stimulation of cholinergic and non-adrenergic non-cholinergic (NANC) nerves in guinea pigs. ${ }^{10}$

The peptide tachykinin, neurokinin A (NKA), exhibits a range of features which may be relevant to the pathophysiology of asthma, including contraction of airway smooth muscle, increased vascular permeability, mucus secretion, and activation of cholinergic neurotransmission. ${ }^{11}{ }^{12}$ Immunocytochemical studies have demonstrated the presence of NKA and its related receptors within the human airways. ${ }^{1314}$ When administered by inhalation to asthmatic subjects NKA elicits dose-related bronchoconstriction, with the asthmatic subjects being more responsive than normal individuals. ${ }^{15-19}$ The mode of action by which NKA elicits bronchoconstriction in asthma is not well understood. The bronchoconstrictor effect of nebulised NKA in asthmatic patients is inhibited by prior treatment with nedocromil sodium, ${ }^{1720}$ suggesting that this response may be evoked indirectly rather than through direct stimulation of airway smooth muscle. In addition, there is recent evidence for an action of NKA in eliciting bronchoconstriction through activation of cholinergic pathways. ${ }^{21}$

We have therefore investigated the effect of prior administration of frusemide, given by inhalation, on the airways response of asthmatic subjects to NKA and to histamine which was included to evaluate the specificity of inhaled frusemide in the response.

\section{Methods}

SUBJECTS

Eleven asthmatic subjects (eight women) with a mean (SE) age of 34.5 (3.6) years referred to our chest clinic with stable asthma participated in the study (table 1). They were nonsmokers and all were atopic as defined by positive skin prick tests ( $>3 \mathrm{~mm}$ weal response) to one or more of six common aeroallergens (Dermatophagoides pteronyssinus, Dermatophagoides farinae, wall pellitory grass, mixed grass pollens, 
Table 1 Demographic details of subjects studied

\begin{tabular}{lllllll}
\hline $\begin{array}{l}\text { Subject } \\
\text { no. }\end{array}$ & Sex & $\begin{array}{l}\text { Age } \\
\text { (years) }\end{array}$ & $\begin{array}{l}\text { Baseline } F E V_{1} \\
\text { (\% predicted) }\end{array}$ & Atopyt & $\begin{array}{l}P_{C_{20} \text { histamine }} \\
(\mathrm{mg} / \mathrm{ml})\end{array}$ & $\begin{array}{l}P C_{20} \mathrm{NKA} \\
(\mu g / \mathrm{ml})\end{array}$ \\
\hline 1 & $\mathrm{M}$ & 21 & 81 & $\mathrm{D}-\mathrm{P}$ & 1.60 & 153.3 \\
2 & $\mathrm{~F}$ & 38 & 115 & $\mathrm{P}$ & 1.59 & 254.9 \\
3 & $\mathrm{~F}$ & 26 & 79 & $\mathrm{P}$ & 0.51 & 313.7 \\
4 & $\mathrm{~F}$ & 41 & 100 & $\mathrm{D}$ & 0.40 & 87.1 \\
5 & $\mathrm{~F}$ & 19 & 89 & $\mathrm{D}-\mathrm{G}$ & 0.38 & 114.1 \\
6 & $\mathrm{M}$ & 22 & 92 & $\mathrm{D}-\mathrm{G}-\mathrm{P}$ & 0.50 & 476.5 \\
7 & $\mathrm{M}$ & 43 & 72 & $\mathrm{P}$ & 0.37 & 60.7 \\
8 & $\mathrm{~F}$ & 56 & 70 & $\mathrm{D}$ & 0.35 & 106.7 \\
9 & $\mathrm{~F}$ & 40 & 82 & $\mathrm{P}$ & 0.56 & 36.8 \\
10 & $\mathrm{~F}$ & 44 & 70 & $\mathrm{D}$ & 0.19 & 114.3 \\
11 & $\mathrm{~F}$ & 26 & 86 & & 1.04 & $141.2 *(36.8-476.5)$ \\
\hline
\end{tabular}

$\mathrm{FEV}_{1}=$ forced expiratory volume in one second; $\mathrm{PC}_{20}=$ provocation concentration producing a $20 \%$ fall in $\mathrm{FEV}_{1}$. Geometric mean (range).

† Atopic, positive immediate skin test to one or more allergens: $\mathrm{D}=$ Dermatophagoides, $\mathrm{P}=$ Parietaria pollen, $\mathrm{G}=$ grass pollen .

cat fur, dog hair). At the beginning of the study all subjects were asymptomatic with a baseline forced expiratory volume in one second $\left(\mathrm{FEV}_{1}\right)$ of $>70 \%$ of their predicted values. None had received oral or topical steroids, theophylline, antihistamines, or sodium cromoglycate within the preceding four weeks. Inhaled bronchodilators were discontinued for at least eight hours before each visit to the laboratory. Subjects were not studied within four weeks of an upper respiratory tract infection or exacerbation of their asthma and all visits to the laboratory were carried out at the same time of day and outside the pollen season.

The study was approved by the ethical subcommittee of the Department of Respiratory Diseases (University of Catania) and all subjects gave their informed consent.

\section{BRONCHIAL PROVOCATION}

Airway calibre was recorded before and during the provocation as $\mathrm{FEV}_{1}$ using a dry wedge spirometer (Vitalograph, Buckinghamshire, UK), the better of the two consecutive measurements being used for analysis.

Histamine (Sigma Chemical Co, St Louis, Missouri, USA) and NKA (Peninsula Laboratories Ltd) were made up in $0.9 \%$ sodium chloride ( $1 \%$ albumin solution) to produce a range of increasing doubling concentrations of $0.03-16.00 \mathrm{mg} / \mathrm{ml}$ and $3.9-500 \mu \mathrm{g} / \mathrm{ml}$, respectively. The aqueous solutions were administered as aerosols generated from a starting volume of $3 \mathrm{ml}$ in a disposable Inspiron mininebuliser (C R Bard International, Sunderland, UK) driven by compressed air at $81 / \mathrm{min}$. Under these conditions the nebuliser had an output of $0.48 \mathrm{ml} / \mathrm{min}$ and generated an aerosol with a mass median particle diameter of $4.7 \mu \mathrm{m} .{ }^{22}$ Wearing a nose clip, subjects inhaled the aerosolised solutions in five breaths from end-tidal volume to full inspiratory capacity via a mouthpiece as described by Chai et al. ${ }^{23}$ Subjects were trained to take three seconds to reach full inspiratory capacity.

STUDY DESIGN

The study consisted of two distinct phases.
Phase 1

Subjects attended the laboratory on two separate occasions, at least 72 hours apart, to undertake concentration-response studies with inhaled histamine and NKA in the absence of any drug treatment.

On the first occasion, after 15 minutes rest, three baseline measurements of $\mathrm{FEV}_{1}$ were made at intervals of three minutes followed by inhalation of $0.9 \%$ sodium chloride and further $\mathrm{FEV}_{1}$ measurements were repeated at one and three minutes. Provided $\mathrm{FEV}_{1}$ had not fallen by more than $10 \%$ of the baseline value, a histamine concentration-response study was carried out. After administration of each histamine concentration $\mathrm{FEV}_{1}$ was measured at one and three minutes. Increasing doubling concentrations of histamine were inhaled at five minute intervals until $\mathrm{FEV}_{1}$ had fallen by more than $20 \%$ of the post-saline baseline value. The fall in $\mathrm{FEV}_{1}$ following each concentration of agonist was expressed as a percentage of the higher of the two post-saline baseline $\mathrm{FEV}_{1}$ recordings. The percentage fall in $\mathrm{FEV}_{1}$ was plotted against the cumulative concentration of agonist on a logarithmic scale and the provocation concentration required to produce a $20 \%$ decrease in $\mathrm{FEV}_{1}$ from the postsaline baseline value $\left(\mathrm{PC}_{20}\right)$ was determined by linear interpolation. On the second occasion a bronchial provocation test with inhaled NKA was undertaken in a similar manner to that described for histamine. $\mathrm{FEV}_{1}$ measurements were recorded one and three minutes after inhalation of each concentration of NKA and the corresponding $\mathrm{PC}_{20} \mathrm{FEV}_{1}$ values derived.

Phase 2

Subjects attended the laboratory on four separate occasions, at least four days apart, to undertake concentration-response studies with histamine and NKA after receiving nebulised frusemide (Lasix, Hoechst, Frankfurt AM Main, Germany) or matched placebo administered double blind and in random order 10 minutes before challenge. The dosage of inhaled frusemide used in the present study and the timing of administration before bronchial challenge were chosen on the basis of previous 
studies. ${ }^{78}$ Both the active and placebo solutions were freshly prepared by an independent investigator on the basis of a randomised code and then returned to the conducting physician to administer to the attending subject. On each occasion, after 15 minutes rest, three baseline measurements of $\mathrm{FEV}_{1}$ were made at intervals of three minutes followed by inhalation of nebulised frusemide $(10 \mathrm{mg} / \mathrm{ml}, 4 \mathrm{ml})$ or nebulised vehicle placebo consisting of $0.9 \%$ sodium chloride adjusted to the same $\mathrm{pH}$ and tonicity as the frusemide. The aerosol solutions were generated from a starting volume of $4 \mathrm{ml}$ in an Inspiron mini-nebuliser driven by compressed air at $81 / \mathrm{min}$ and inhaled to dryness by deep tidal breathing over 7-9 minutes. The same nebuliser was used for all studies on all subjects. Further $\mathrm{FEV}_{1}$ measurements were repeated at one, five, and 10 minutes after drug/placebo inhalation and dose-response studies with increasing concentrations of histamine and NKA were carried out in a similar manner to that described in phase 1 .

\section{DATA ANALYSIS}

Results are expressed as mean (SE) unless otherwise stated and $\mathrm{p}$ values of $<0.05$ were accepted as the minimum level of statistical significance. Baseline values of $\mathrm{FEV}_{1}$ before and after treatment were compared between and within study days by two-factor analysis of variance (ANOVA).

After nebulised frusemide a $20 \%$ fall in $\mathrm{FEV}_{1}$ was not obtained in five subjects (nos 1-4 and 7) at the highest concentration of NKA administered, and therefore a minimal estimate was obtained by calculating the cumulative $\mathrm{PC}_{20}$ on the next doubling concentration beyond the highest administered. Because of these censored data the results were compared for significance with Wilcoxon's signed rank test. Values of $\mathrm{PC}_{20}$ histamine and NKA following treatment with frusemide and placebo were log-transformed and compared by means of two-factor ANOVA.

Concentration ratios for the effect of frusemide against bronchoprovocation with each agonist were calculated individually by dividing the $\mathrm{PC}_{20}$ value obtained after the active drug by that obtained after placebo and compared using the Wilcoxon's signed rank test. The relationship between the airway responses to histamine and NKA was tested by least squares

Table 2 Effects of pretreatment with inhaled frusemide and placebo on airway NKA and histamine responsiveness

\begin{tabular}{|c|c|c|c|c|}
\hline \multirow{2}{*}{$\begin{array}{l}\text { Subject } \\
\text { no. }\end{array}$} & \multicolumn{2}{|c|}{$P C_{20} N K A(\mu g / m l)$} & \multicolumn{2}{|c|}{$P C_{20}$ histamine $(\mathrm{mg} / \mathrm{ml})$} \\
\hline & Placebo & Frusemide & Placebo & Frusemide \\
\hline 1 & 205.2 & 1000 & 3.80 & 4.33 \\
\hline 2 & 169.6 & 1000 & 2.12 & 3.38 \\
\hline 3 & 326.0 & 1000 & 0.19 & 0.28 \\
\hline 4 & 250.4 & 1000 & 0.44 & 1.66 \\
\hline 5 & 46.9 & 178.3 & 0.28 & 0.35 \\
\hline 6 & 126.4 & 211.5 & 0.90 & 0.80 \\
\hline 7 & 378.8 & 1000 & 0.24 & 1.80 \\
\hline 8 & 35.8 & 126.5 & 0.44 & 1.45 \\
\hline 9 & 109.4 & 210.0 & 1.25 & 0.90 \\
\hline 10 & 61.2 & 384.6 & 0.12 & 0.39 \\
\hline 11 & 121.1 & 177.3 & 0.86 & 0.86 \\
\hline Geometric mean & 130.3 & 419.9 & 0.58 & 1.04 \\
\hline (range) & $(35.8-378.8)$ & $(126.5-1000)$ & $(0.12-3.80)$ & $(0.28-4.33)$ \\
\hline
\end{tabular}

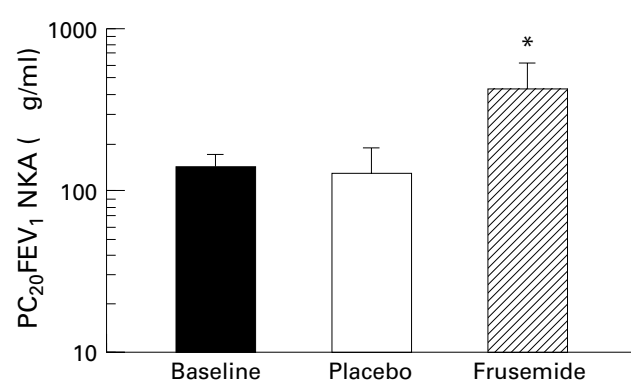

Figure 1 Mean (SE) changes in provocation concentrations of NKA required to provoke a $20 \%$ decrease in $F E V_{1}\left(P C_{20} F E V_{1}\right)$ on baseline, placebo, and frusemide study days in 11 asthmatic subjects. ${ }^{*} p<0.01$ versus placebo.

linear regression analysis of their log-transformed $\mathrm{PC}_{20}$ values. Linear regression analysis was also used to evaluate any relationship between the concentration ratios after the drug and the airway responses to histamine and NKA.

\section{Results}

There was no significant difference in mean (SE) baseline values of $\mathrm{FEV}_{1}$ between any of the study days, with values ranging from 2.37 (0.19) 1 to $2.44(0.18)$ 1. Administration of frusemide did not cause any change in $\mathrm{FEV}_{1}$ from baseline on either NKA or histamine study days. Mean values of $\mathrm{FEV}_{1}$ following administration of frusemide were not significantly different from those after placebo when compared at all time points.

Inhaled histamine and NKA produced concentration-related falls in $\mathrm{FEV}_{1}$. The geometric mean (range) of $\mathrm{PC}_{20}$ values obtained were 0.55 $(0.19-1.60) \mathrm{mg} / \mathrm{ml}$ and $141.2(36.8-476.5) \mu \mathrm{g} /$ $\mathrm{ml}$ for histamine and NKA, respectively (table 1). No significant correlation was observed between $\mathrm{PC}_{20}$ values for histamine and NKA.

When compared with placebo, inhaled frusemide had a significant protective effect against the fall in $\mathrm{FEV}_{1}$ produced by NKA. Frusemide produced a displacement of the NKA concentration-response curve to the right in all the subjects studied. For these subjects the geometric mean (range) $\mathrm{PC}_{20} \mathrm{NKA}$ values increased 3.5-fold from $130.3(35.8-378.8) \mu \mathrm{g} /$ $\mathrm{ml}$ to $419.9(126.5-1000) \mu \mathrm{g} / \mathrm{ml}$ after placebo and frusemide, respectively ( $\mathrm{p}<0.01$; fig 1 , table $2)$. No correlation could be found between baseline airway reactivity and the protection of airway response to NKA after frusemide exposure.

In addition, inhaled frusemide elicited a small but significant protection against the airway response to histamine $(\mathrm{p}<0.05)$, the geometric mean (range) $\mathrm{PC}_{20}$ histamine value increasing 1.7-fold from $0.58(0.12-3.80) \mathrm{mg} /$ $\mathrm{ml}$ to $1.04(0.28-4.33) \mathrm{mg} / \mathrm{ml}$ after placebo and frusemide, respectively (fig 2, table 2). Finally, no relationship was found between the concentration ratios for the effect of frusemide against bronchoprovocation with NKA and histamine $(\mathrm{p}=\mathrm{NS} ; r=0.10)$. 


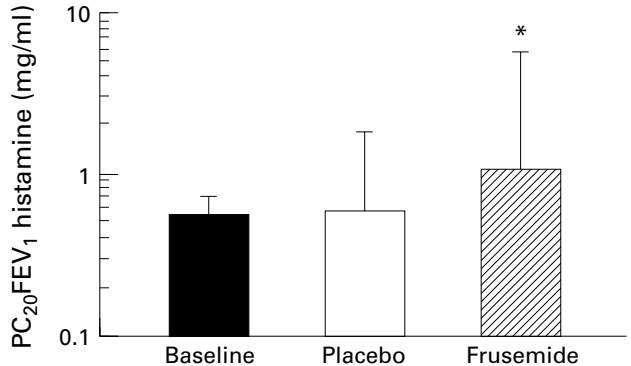

Figure 2 Mean (SE) changes in provocation concentrations of histamine required to provoke a $20 \%$ decrease in $F E V_{1}\left(P C_{20} F E V_{1}\right)$ on baseline, placebo, and frusemide study days in 11 asthmatics. ${ }^{*} p<0.05$ versus placebo.

\section{Discussion}

This study confirms previous findings that inhaled NKA causes dose-related bronchoconstriction in asthmatic subjects. ${ }^{15-19}$ We have also shown that frusemide administered by inhalation elicits protection of the airways against bronchoconstriction provoked by NKA in all the asthmatic subjects studied. In addition, we have shown a small but significant change in airway responsiveness to histamine following frusemide exposure. The protection afforded by frusemide was twice as great against NKA as against histamine, which suggests involvement of several mechanisms.

The approximately 3.5 -fold displacement of the concentration-response curves to the right with NKA is similar to that reported with other indirectly acting bronchoconstrictor stimuli and is similar to that observed after disodium cromoglycate or nedocromil sodium. In addition, the observation that inhaled frusemide and disodium cromoglycate/nedocromil sodium have little or no significant protective effect against methacholine-induced bronchoconstriction in asthma ${ }^{5-724}$ suggests that these drugs have indirect effects. There is now considerable evidence to support the hypothesis that frusemide has an inhibitory effect on neural pathways in the airways. Frusemide has been shown to inhibit the cough response induced by low chloride solutions in $\operatorname{dogs}^{25}$ and normal volunteers, ${ }^{9}$ and both frusemide and bumetanide produce dose-dependent inhibition of the contractile response of airways smooth muscle induced by stimulation of cholinergic and noncholinergic non-adrenergic nerves in guinea pigs. ${ }^{10}$ Similarly, Verleden et $a l^{26}$ have recently shown that loop diuretics elicit a dose-dependent inhibition of cholinergic neurotransmission in human airways in vitro, possibly via an action on ion channels located on these nerves. Although the bronchoconstrictor activity of NKA is markedly inhibited by nedocromil sodium, ${ }^{1720}$ the selective histamine $\mathrm{H}_{1}$ receptor antagonist, terfenadine, does not appear to protect against NKA-induced bronchoconstriction. ${ }^{27}$ Furthermore, anticholinergic blockade also affords protection against this agonist. ${ }^{21}$ These findings, together with the results of the present investigation, suggest that excitation of neural pathways may underlie NKA responses in human asthma. However, the exact stimulus prompting the neural reflex activation remains to be clarified. A possibility may include an indirect activation of cholinergic reflexes through the production of prostaglandins. There is evidence in vitro that part of the biological effects of exogenously applied neuropeptides may result from the local release of bioactive prostaglandins. ${ }^{28}$ Indeed, we have recently shown a significant decrease in airway responsiveness to NKA after cyclooxygenase blockade. ${ }^{29}$

The contribution of alternative protective mechanisms of inhaled frusemide in NKAinduced bronchoconstriction must be considered. Prostaglandin release may be involved in the protective effects of frusemide. Loop diuretics have been shown to induce their effect in the kidney by the secondary production of the prostaglandins $\mathrm{PGE}_{2}$ and $\mathrm{PGI}_{2} \cdot{ }^{3031}$ In man frusemide stimulates the production of $\mathrm{PGE}_{2}$ by increasing the availability for arachidonic $\operatorname{acid}^{32}$ and enhances the urinary excretion of $\mathrm{PGI}_{2}{ }^{33}$ Since the inhibitory effect of loop diuretics on nerve activation in human airways in vitro is related to the release of endogenous cyclooxygenase products from the epithelium, ${ }^{26}$ it is suggested that frusemide may afford airway protection by releasing epithelium derived $\mathrm{PGE}_{2}$ and $\mathrm{PGI}_{2}$, both of which are potent functional antagonists. Other in vitro experiments in the guinea pig trachea also suggest an influence of inhibitory prostaglandins. ${ }^{34}$ In addition, $\mathrm{PGE}_{2}$ has been shown to inhibit airway neurotransmission in human bronchial preparations. ${ }^{35}$ Recent data by Pavord et $a l^{36}$ and by us ${ }^{37}$ support the view that the prevention of bronchoconstrictor stimuli by loop diuretics in human airways may be due to the local production of inhibitory prostaglandins. Thus, the inhibitory action of inhaled frusemide against NKA-induced bronchoconstriction is likely to be due to a suppressive action on the activation of neural pathways or to the local production of inhibitory prostaglandins with functional antagonistic effects.

In this study we have also shown a small but significant effect of frusemide against histamine-induced bronchoconstriction. Although this finding is in keeping with the data reported by Vaghi et al, ${ }^{38}$ two previous studies failed to show any significant effect of frusemide on histamine responses in both adult and paediatric asthmatic subjects. ${ }^{390}$ There may be factors in the characteristics of these patients which affects their response to frusemide. The asthmatic subjects studied in the present investigation differ from those in the studies of O'Connor et $a l^{39}$ and Mochizuki et $a l^{40}$ for having a considerably higher degree of bronchial hyperresponsiveness. Moreover, Mochizuki et al found that inhaled frusemide afforded protection against bronchoconstriction only in the child with the highest degree of bronchial hyperresponsiveness. Bronchial hyperresponsiveness correlates with the extent of epithelial damage in human asthma. Damaged airway epithelium may alter the pharmacokinetic profile of inhaled loop diuretics, thus changing their local pharmacodynamic activity. It is therefore possible that higher drug 
concentrations are penetrating deeper in the bronchial mucosa of those asthmatic subjects with the highest degree of bronchial hyperreactivity so that a more significant response is seen.

Histamine elicits bronchoconstriction by stimulating specific receptors and, to a lesser extent, via cholinergic activation. In support of the ability of histamine to influence vagal airway tone, both atropine and inhaled ipratropium bromide ${ }^{4142}$ have been shown to be effective inhibitors of histamine-induced bronchoconstriction through cholinergic blockade. Thus, as shown for NKA, the small protection of inhaled frusemide against histamine-induced bronchoconstriction may be due to a suppressive action on the activation of neural pathways or to the local production of inhibitory prostaglandins with functional antagonistic effects. However, the lack of correlation between the protective effect against NKA and histamine argues against this possibility.

In conclusion, our results demonstrate that inhaled frusemide produces protection against NKA-provoked bronchoconstriction in asthmatic subjects and indicate a role either for the inactivation of neural pathways or the local production of inhibitory prostaglandins. Whatever the mechanism, the present findings further support the view that the mechanism of action of NKA in asthma is likely to be indirect. However, further work is necessary to investigate the exact role and the mode of action of NKA in human airways.

1 Polosa R. Inhaled loop diuretics: how do we interpret their modulatory role in asthma? Allergy 1993;48:555-8.

2 Bianco S, Pierono MG, Refini RM, Rottoli L, Sestini P. Protective effect of inhaled frusemide on allergen-induced early and late asthmatic reactions. $N$ Engl f Med 1989; 321:1069-73.

3 Robuschi M, Gambard G, Spagnotto S, Vaghi A, Bianco $\mathrm{S}$. Inhaled frusemide is highly effective in preveting ultra-
sonically nebulised water bronchoconstrction. Pulm Pharsonically nebulised wat

4 Bianco S, Vaghi A, Robuschi M, Pasargiklian M. Prevention of exercise-induced bronchoconstriction by inhaled frusemide. Lancet 1988;ii:252-5.

5 Grubbe RE, Hopp R, Dave NK, Brennan B, Bewtra A, Townley R. Effect of inhaled furosemide on the bronchial response to methacholine and cold air hyperventilation challenges. F Allergy Clin Immunol 1990;85:881-4.

6 Nichol GM, Alton EWFW, Nix A, Geddes DM, Chung $\mathrm{KF}$, Barnes PJ. Effect of inhaled furosemide on metabisulfite- and methacholine-induced bronchoconstriction and nasal potentials in asthmatic subjects. Am Rev Respir Dis 1990;142:576-80.

7 Polosa R, Lau LCK, Holgate ST. Inhibition of adenosine 5 -monophosphate- and methacholine-induced bronchoconstriction in asthma by inhaled frusemide. Eur Respir f 1990;3:665-72.

8 Rajakulasingam K, Polosa R, Church MK, Howarth PH, Holgate ST. Effect of inhaled frusemide on responses of airways to bradykinin and adenosine $5^{\prime}$-monophosphate in asthma. Thorax 1994;49:485-91.

9 Ventresca PG, Nichol GM, Barnes PJ, Chung KF. Inhaled furosemide inhibits cough induced by low chloride content solutions but not by capsaicin. Am Rev Respir Dis 1990; 142:143-6.

10 Elwood W, Lotvall JO, Barnes PJ, Chung KF. Loop diuretics inhibit cholinergic and noncholinergic nerves in guinea pig airways. Am Rev Respir Dis 1991;143:1340-4.

11 Barnes PJ, Baraniuk JN, Belvisi MG. Neuropeptides in the respiratory tract. Am Rev Respir Dis 1991;144:1187-98.

12 Joos GF, Germonpre PR, Pauwels RA. Neurogenic inflammation in human airways: is it important? Thorax 1995;50:217-9.

13 Hislop AA, Wharton J, Allen KM, Polak JM, Haworth SG. Immunohistochemical localization of peptide-containing nerves in human airways: age-related changes. Am f Respir nerves in human airways: age-
Cell Mol Biol 1990;3:191-8.

14 Baraniuk JN, Lundgren JS, Okayama M, Goff J, Mullol J, et al. Substance $\mathrm{P}$ and neurokinin $\mathrm{A}$ in human nasal mucosa. Am $\mathcal{F}$ Respir Cell Mol Biol 1991;4:228-36.
15 Joos G, Pauwels R, Van der Straeten M. The effect of inhaled substance $\mathrm{P}$ and neurokinin $\mathrm{A}$ on the airways of normal and asthmatic subjects. Thorax 1987;42:779-83.

16 Crimi N, Palermo F, Oliveri R, Palermo B, Vancheri C, Polosa R, et al. Effect of nedocromil on bronchospasm induced by inhalation of substance $P$ in asthmatic subjects. Clin Allergy 1988;18:375-82.

17 Crimi N, Palermo F, Oliveri R, Palermo B, Polosa R, Mistretta A. Protection of nedocromil sodium on bronchoconstriction induced by inhaled neurokinin $\mathrm{A}$ in asthmatic patients. Clin Exp Allergy 1992;22:75-81.

18 Cheung D, Bel EH, den Hartigh J, Dijkman JH, Sterk PJ. The effect of an inhaled NEP inhibitor, thiorphan, on airway responses to neurokinin A in normal humans in airway responses to neurokinin A in normal
vivo. Am Rev Respir Dis 1992;145:1275-80.

19 Cheung D, Timmers MC, Zwinderman AH, den Hartigh J, Dijkman JH, Sterk PJ. NEP activity and airway hyperresponsiveness to neurokinin $\mathrm{A}$ in asthmatic subjects in vivo. Am Rev Respir Dis 1993;148:1467-73.

20 Joos G, Pauwels R, Van der Straeten M. The effect of nedocromil sodium on the bronchoconstrictor effect of neurokinin A in subjects with asthma. F Allergy Clin Immunol 1989;83:663-8

21 Joos GF, Pauwels RA, Van der Straeten ME. The effect of oxitropium bromide on neurokinin A-induced bronchoconstriction in asthmatics. Pulm Pharmacol 1988;1: 41-5.

22 Lewis RA. Therapeutic aerosols. In: Bonsignore GCC, ed. Drugs and the lung. London: Plenum, 1984: 63-86.

23 Chai H, Farr RS, Froehlich LA, Mathison DA, McLean JA, Sheffer AL, et al. Standardization of bronchial inhalation challenge procedures. $\mathcal{F}$ Allergy Clin Immunol 1975;56:

24 Griffin MP, MacDonald N, McFadden ER. Short and long term-term of cromolyn sodium on airway reactivity of asthmatics. F Allergy Clin Immunol 1983;71:331-8.

25 Sant Ambrogio FB, Sant Ambrogio G, Anderson JW. Effect of furosemide on the response of laryngeal receptors to low-chloride solutions. Eur Respir 7 1993;6:1151-5.

26 Verleden GM, Pype JL, Deneffe G, Demedts MG. Effect of loop diuretics on cholinergic neurotransmission in human airways in vitro. Thorax 1994;49:657-63.

27 Crimi N, Oliveri R, Polosa R, Palermo F, Mistretta A The effect of oral terfenadine on neurokinin A-induced bronchoconstriction. F Allergy Clin Immunol 1993;91: 1096-8.

28 Frossard N, Rhoden KJ, Barnes PJ. Influence of epithelium on guinea pig airway responses to tachykinins: role of endopeptidase and cyclooxygenase. F Pharmacol Exp Ther 1989;248:292-8.

29 Crimi N, Polosa R, Prosperini G, Magrì S, Ciamarra I, Mistretta A. Changes in NKA airways responsiveness with inhaled L-ASA in asthma. Eur Respir f 1996;9:1139-45.

30 Mackay IG, Muir AL, Watson ML. Contribution of the prostaglandins to the systemic and renal vascular response prostaglandins to the systemic and renal vascular response

31 Miyanoshita A, Terada M, Endou H. Furosemide directly stimulates $\mathrm{PGE}_{2}$ production in the thick ascending limb of Henle's loop. f Pharmacol Exp Ther 1989;251:1155-9.

32 Weber PC, Scherer B, Larsson C. Increase of free arachidonic acid by frusemide in man as the cause of prostaglandin and renin release. Eur $\mathcal{F}$ Pharmacol 1977; 41:329-32.

33 Scherer B, Weber PC. Time-dependent changes in prostaglandin excretion in response to frusemide in man. Clin Sci 1979;56:77-81

34 Molimard M, Advenier C. Effect of furosemide on bradykinin- and capsaicin-induced contraction of the guinea pig trachea. Eur Respir $\mathcal{F}$ 1993;6:434-9.

35 Ito I, Suzuki H, Aizawa H, Hirose T, Hakoda H. Prejunctional inhibitory action of $\mathrm{PGE}_{2}$ on excitatory neuroeffector transmission in the human bronchus. Prostaglandins 1990;39:639-55.

36 Pavord ID, Wisniewski A, Tattersfield AE. Inhaled frusemide and exercise induced asthma: evidence of a role for inhibitory prostanoids. Thorax 1992;47:797-800

37 Polosa R, Rajakulasingam K, Prosperini G, Magrì S, Mastruzzo C, Holgate ST. Inhaled loop diuretics and basal airway responsiveness in man: evidence of a role fo cyclooxygenase products. Eur Respir f 1995;8:593-9.

38 Vaghi A, Robuschi M, Berni F, Bianco S. Effect of inhaled frusemide $(\mathrm{F})$ on bronchial response to histamine $(\mathrm{H})$ in asthmatics. Eur Respir f 1988;1 (Suppl 2):406s.

39 O'Connor BJ, Chung KF, Chen-Wordsdell YM, Fuller RW, Barnes PJ. Effect of inhaled furosemide and bumetanide on AMP and sodium metabisulfite-induced bronchoconstriction in asthmatic subjects. Am Rev Respir Dis 1991 143:1329-33.

40 Mochizuki H, Shimizu T, Maeda S, Tokuyama K, Morikawa A, Kuroume T. Relationship between ultrasonically nebulized distilled water-induced bronchoconstriction and acetic acid-induced cough in asthmatic children. $\mathcal{F}$ Allergy Clin Immunol 1995;96:193-9.

41 Sheppard D, Epstein J, Skoogh BE, Bethel RA, Nadel JA Boushey HA. Variable inhibition of histamine-induced bronchoconstriction by atropine in subjects with asthma. bronchoconstriction by atropine in subje

42 Polosa R, Phillips GD, Rajakulasingam K, Holgate ST. The effect of inhaled ipratropium bromide alone and in The effect of inhaled ipratropium bromide alone and in provoked by AMP and histamine in asthma. $\mathcal{f}$ Allergy Clin provoked by AMP and his 